\title{
ANALISIS KEBUTUHAN PENGEMBANGAN LEMBAR KERJA PESERTA DIDIK BERBASIS ANDROID
}

\author{
Adjie Pamungkas ${ }^{\text {a) }}$, Acep Kusdiwelirawan ${ }^{\text {b) }}$ \\ Program Studi Pendidikan Fisika, Fakultas Keguruan dan Ilmu Pendidikan, Universitas Muhammadiyah Prof. \\ Dr. Hamka, Jl. Tanah Merdeka No.20, DKI Jakarta 13830, Indonesia \\ Email: a)adjie.pamungkas766@gmail.com, b)acep_galing@uhamka.ac.id
}

\begin{abstract}
Abstrak
Lembar kerja peserta didik merupakan salah satu bahan ajar yang memiliki peranan sangat penting dalam proses pembelajaran. Dengan adanya lembar kerja peserta didik, diharapkan peserta didik dapat terlibat secara aktif dalam proses pembelajaran. Lembar kerja yang banyak digunakan saat ini adalah lembar kerja dalam bentuk cetak yang disediakan oleh pendidik dan lembar kerja yang bersumber dari buku paket. Tujuan dari penelitian ini adalah untuk mengetahui respon peserta didik terhadap rancangan pengembangan lembar kerja peserta didik berbasis android. Subjek penelitian adalah peserta didik sekolah menengah atas negeri dan swasta di wilayah Bekasi dan Jakarta. Sampel dipilih secara acak sebanyak 40 peserta didik. Data dikumpulkan dengan menggunakan lembar angket analisis kebutuhan oleh peserta didik yang selanjutnya dianalisis secara deskriptif kualitatif. Hasil analisis angket kebutuhan menunjukkan bahwa 1) peserta didik membutuhkan media berupa video dan tidak hanya berupa gambar/grafik, 2) tampilan lembar kerja mobile yang dikembangkan diharapkan memiliki desain yang menarik, 3) jawaban hasil kerja peserta didik diharapkan dapat langsung diinput dan tersimpan pada lembar kerja mobile yang dikembangkan. Analisis kebutuhan ini merupakan bagian dari studi awal pengembangan aplikasi lembar kerja peserta didik berbasis android yang mampu mendukung peningkatan inovasi dalam perkembangan teknologi dibidang pendidikan.
\end{abstract}

Kata-kata kunci: Analisis, Lembar Kerja Peserta Didik, Android.

\begin{abstract}
Student worksheets are one of the teaching materials that have a significant role in the learning process. With the student worksheets, students are expected to be actively involved in the learning process. Worksheets that are widely used today are printed worksheets provided by educators and worksheets sourced from textbooks. This study aimed to determine students' responses to the design of developing an Android-based student worksheet. Research subjects were state and private high school students in Bekasi and Jakarta. The sample was chosen at random as many as 40 students. Data were collected using a needs analysis questionnaire sheet by students who then analyzed descriptive qualitatively. The results of the needs questionnaire analysis show that 1 ) students need media in the form of video and not just pictures / graph pictures/graphics developed mobile worksheets is expected to have an attractive design, 3) answers of students' work are expected to be directly inputted and stored on mobile worksheets developed. This needs analysis is part of the initial study of developing an Android-based student worksheet application that is able to support increased innovation in technological development in the field of education.
\end{abstract}


Keywords: Analysis, Student Worksheets, Android.

\section{PENDAHULUAN}

Pesatnya perkembangan ilmu pengetahuan dan teknologi tentunya akan selalu berdampingan dengan perkembangan pendidikan. Teknologi dalam pendidikan berperan penting dalam proses penyampaian ilmu pengetahuan sehingga dapat memudahkan pelaksanaan pembelajaran [1]. Perkembangan ilmu pengetahuan dan teknologi semakin mendorong upaya-upaya pembaharuan dalam pemanfaatan hasil teknologi dalam proses belajar. Sehingga hadirnya teknologi pada proses pembelajaran sangat diperlukan agar proses pembelajaran menjadi lebih efektif dan peserta didik dapat terlibat aktif sepenuhnya dalam proses pembelajaran.

Kurikulum 2013 adalah kurikulum yang berpusat pada peserta didik agar lebih aktif dalam proses pembelajaran dan pendidik bertindak sebagai fasilitator. Seiring dengan perkembangan teknologi pendidik dituntut untuk mampu memanfaatkan teknologi dalam meningkatkan mutu pembelajaran, yaitu dengan memanfaatkan sumber belajar berbasis komputer atau android. Penggunaan sumber belajar, sangat berpengaruh pada proses pembelajaran, karena melalui sumber belajar tersebut akan terlihat bagaimana peserta didik terlibat dalam proses pembelajaran tidak semata-mata hanya mendengarkan apa yang dijelaskan oleh pendidik tetapi mereka juga dituntut untuk menganalisis sendiri [2].

Sumber belajar adalah sesuatu yang dapat dimanfaatkan oleh pendidik baik secara terpisah maupun bentuk gabungan untuk kepentingan belajar-mengajar dengan tujuan meningkatkan efektivitas dan efisiensi tujuan belajar. Bahan ajar merupakan bagian dari sumber belajar yang perlu dikembangkan oleh pendidik. Terdapat jenis bahan ajar dalam proses belajar mengajar salah satunya adalah lembar kerja peserta didik [2].

Lembar kerja peserta didik berfungsi untuk mempermudah pemahaman peserta didik dalam mempelajari suatu materi. Lembar kerja peserta didik ini berisi tugas yang dapat mengarahkan peserta didik untuk mencari sendiri pengetahuannya terhadap materi yang sedang dipelajari [3]. Pada lembar kerja peserta didik disusun cara kerja, buku penunjang, waktu yang diperlukan untuk melaksanakan kegiatan, bahkan dapat dilengkapi dengan tabel untuk menulis kegiatan yang diamati [4]. Lembar kerja peserta didik merupakan salah satu bentuk fasilitas yang digunakan pendidik dalam memfasilitasi peserta didik dalam proses pembelajaran sesuai dengan kurikulum 2013.

Pada hasil observasi mengenai lembar kerja yang digunakan peserta didik pada empat sekolah menengah atas di wilayah Bekasi dan Jakarta, jenis lembar kerja cetak adalah lembar kerja yang paling banyak digunakan dalam proses pembelajaran. Lembar kerja cetak tersebut merupakan lembar kerja yang bersifat satu arah yaitu lembaran yang memuat materi yang akan dibahas dan berisi langkah kerja yang harus dilakukan oleh peserta didik. Namun Lembar kerja cetak ini dinilai kurang membangkitkan semangat belajar peserta didik, peserta didik mudah merasa bosan, dan kurang tertarik untuk belajar dan bahan ajar yang digunakan juga kurang menarik. Sehingga peserta didik yang diperbolehkan untuk membawa media elektronik handphone terkadang kurang memperhatikan pendidik ketika menjelaskan materi pelajaran [2]. Sehingga lembar kerja yang selama ini dikenal sebagai bahan ajar cetak, dalam perkembangannya LKPD dapat disajikan dalam bentuk interaktif yang berbasis android. Lembar kerja interaktif tidak hanya menyajikan materi, tetapi juga dilengkapi dengan video dan animasi yang dapat menguatkan pemahaman peserta didik dalam mempelajari materi yang disampaikan [2].

Android merupakan salah satu sistem operasi yang banyak digunakan oleh pengguna smartphone. Android adalah sistem operasi berbasis Linux yang dirancang untuk perangkat bergerak layar sentuh seperti telepon pintar dan komputer tablet [5]. Ditambah lagi Android menyediakan platform terbuka bagi para pengembang untuk menciptakan aplikasi mereka sendiri untuk digunakan oleh bermacam peranti bergerak, sehingga aplikasi yang dapat digunakan menjadi sangat beragam [6]. Salah satu alasan android menjadi sistem operasi pupular terutama dibidang pendidikan adalah tingkat efektifitas dan efisiennya yang lebih baik dibandingkan dengan program sejenis lainnya. Pengembang hanya berkonsentrasi pada aplikasi saja, aplikasi tersebut bisa berjalan pada beberapa perangkat berbeda selama masih ditenagai android. 
Mengingat pada kalangan peserta didik khususnya peserta didik SMA atau SMK banyak peserta didik sudah memiliki smartphone. Hal ini dibuktikan dengan hasil survei e-marker pengguna internet Indonesia pada tahun 2016 sebanyak 75,5\% dengan umur 10-24 tahun sebesar 768 ribu anak, dengan anak-anak berusia 10-14 tahun sering melihat video yang diperoleh dari Youtube [7]. Pendidik dapat menggunakan smartphone sebagai alternatif memberikan peserta didik materi dan soal, serta mengorganisasi permasalahan kelas dalam pembelajaran di rumah, selain itu dapat memberikan pembelajaran yang menantang dan meningkatkan motivasi yang sangat baik dan penggunaan LKPD sebagai media belajar yang dikembangkan sesuai dengan teori belajar yang dapat meningkatkan hasil belajar [7].

Dengan menggunakan LKPD berbasis android ini merupakan salah satu upaya untuk mensukseskan tujuan dari kurikulum 2013, dimana peserta didik dituntut untuk berperan aktif dan pendidik hanya sebagai fasilitator pemandu peserta didik dalam proses belajar. pendidik membimbing peserta didik dalam belajar, dan memberikan kebebasan kepada peserta didik untuk menyelidiki, mengamati, belajar dan memecahkan masalah secara mandiri [8]. Manfaat LKPD berbasis android adalah peserta didik dapat dengan mudah mengakses pembelajaran kapanpun dan dimanapun, meningkatkan semangat peserta didik dalam belajar, memberikan pemahaman peserta didik karena peserta didik dapat mengakses gambar dan video di dalamnya karena hal tersebut merupakan perangkat pengajaran yang efektif untuk menarik minat belajar peserta didik [9].

Penelitian ini bertujuan untuk mengetahui informasi awal dan tanggapan peserta didik mengenai lembar kerja peserta didik berbasis android yang dikembangkan. Hasil penelitian yang diperoleh diharapkan dapat menjadi acuan dalam melakukan pengembangan lembar kerja peserta didik berbasis android.

\section{METODOLOGI}

Penelitian ini menggunakan metode survei yang dilaksanakan pada tanggal $8-22$ januari 2020 di empat sekolah menengah atas yang terdiri dari dua sekolah menengah atas negeri dan dua sekolah menengah atas swasta di wilayah Bekasi dan Jakarta. Populasi penelitian adalah peserta didik yang berjumlah 80 orang dari empat sekolah. Sampel dipilih secara acak sebanyak 10 orang dari masingmasing sekolah sehingga total sampel sebanyak 40 orang.

Teknik pengumpulan data dengan penyebaran lembar angket kepada peserta didik. Lembar angket digunakan untuk memperoleh data tentang pengalaman peserta didik dalam menggunakan lembar kerja, sumber lembar kerja peserta didik yang digunakan, serta tanggapan peserta didik mengenai lembar kerja dalam bentuk cetak dan rancangan dalam bentuk mobile melalui smartphone yang akan dikembangkan. Data hasil penelitian dianalisis secara deskriptif kualitatif.

\section{HASIL DAN PEMBAHASAN}

Berdasarkan hasil survei dengan melakukan penyebaran angket pada empat sekolah menengah atas diwilayah Bekasi dan Jakarta diperoleh data pengalaman peserta didik dalam menggunakan lembar kerja dalam proses pembelajaran seperti sumber lembar kerja yang digunakan oleh peserta didik yang ditampilkan pada TABEL 1. Data hasil angket terkait jenis lembar kerja yang digunakan oleh peserta didik ditampilkan pada TABEL 2. Data hasil angket terkait media yang terdapat pada lembar kerja yang digunakan disajikan pada TABEL 3. Serta data mengenai kebutuhan lembar kerja yang dikembangkan berdasarkan tanggapan peserta didik disajikan pada TABEL 4.

TABEL 1. Sumber lembar kerja yang digunakan peserta didik

\begin{tabular}{lc}
\hline \multicolumn{1}{c}{ Sumber Lembar Kerja } & Jumlah $(\boldsymbol{\%})$ \\
\hline Pendidik & 44,8 \\
Buku paket & 34,4 \\
Internet & 20,8 \\
\hline
\end{tabular}

TABEL 2. Jenis lembar kerja yang digunakan peserta didik

\section{Jenis Lembar Kerja}

Lembar kerja cetak (buku/lembaran)

Lembar kerja elektronik (laptop/komputer)
Jumlah $(\%)$

65

10 
TABEL 3. Media yang terdapat pada lembar kerja yang digunakan peserta didik

\begin{tabular}{lc}
\hline \multicolumn{1}{c}{ Media Lembar Kerja } & Jumlah $(\boldsymbol{\%})$ \\
\hline Gambar & 59,2 \\
Video & 15,6 \\
Animasi & 4,4 \\
Simulasi & 20,8 \\
\hline
\end{tabular}

TABEL 4. Tanggapan peserta didik terhadap pengembangan lembar kerja yang dikembangkan

\begin{tabular}{cl}
\hline No. & \multicolumn{1}{c}{ Tanggapan Peserta Didik } \\
\hline 1 & $\begin{array}{l}\text { Desain lembar kerja basis android diharapkan lebih menarik } \\
\text { Peserta didik diharapkan dapat mengisi jawaban langsung pada lembar } \\
\text { kerja basis android }\end{array}$ \\
3 & $\begin{array}{l}\text { Lembar kerja basis android yang dikembangkan diharapkan memiliki } \\
\text { kelebihan yang sama dengan lembar kerja dalam bentuk cetak }\end{array}$ \\
4 & $\begin{array}{l}\text { Lembar kerja basis android diharapkan memiliki fitur penyimpanan } \\
\text { secara online } \\
\text { Pada lembar kerja diharapkan adanya media video, tidak hanya } \\
\text { gambar }\end{array}$ \\
\hline
\end{tabular}

Berdasarkan hasil survei yang telah dilakukan pada empat sekolah menengah atas diwilayah Bekasi dan Jakarta, diperoleh informasi pada bahwa lembar kerja peserta didik merupakan salah satu bahan ajar yang digunakan oleh pendidik dalam proses pembelajaran. Lembar kerja peserta didik digunakan untuk menunjang kegiatan belajar mengajar agar peserta didik berperan aktif dalam proses pembelajaran sesuai dengan kurikulum 2013 yang diterapkan. Pengembangan terhadap lembar kerja peserta didik tentunya sangat diperlukan agar tujuan pembelajaran yang direncanakan dapat tercapai secara maksimal. Pengembangan lembar kerja peserta didik tidak hanya meliputi pengembangan isi konten dari lembar kerja tersebut. Namun seiring dengan perkembangan teknologi yang semakin canggih tentunya perlu dilakukan pengembangan terhadap perangkat yang digunakan, yaitu dari perangkat kertas menjadi perangkat smartphone yang tentunya akan lebih praktis dan efektif serta dapat mendukung kelestarian lingkungan.

Berdasarkan angket yang dibagikan kepada peserta didik diperoleh data pada TABEL 1 bahwa sebanyak 44,8 \% lembar kerja yang digunakan oleh peserta didik dalam proses pembelajaran bersumber dari lembar kerja cetak yang dibagikan oleh pendidik, 34,4 \% lembar kerja yang digunakan bersumber dari buku paket yang terdapat pada bagian kegiatan peserta didik dan 20,8\% bersumber dari internet. Data tersebut menjelaskan bahwa lembar kerja yang digunakan pendidik untuk mendukung proses pembelajaran paling banyak menggunakan lembar kerja yang dirancang oleh pendidik secara mandiri sesuai dengan tujuan pembelajaran dan kebutuhan peserta didik. Sebagaimana dikemukakan oleh Ditentik bahwa seorang pendidik yang profesional dituntut kreativitasnya untuk mampu menyusun bahan ajar yang inovatif, variatif, menarik, kontekstual dan sesuai dengan kebutuhan peserta didik Akan tetapi lembar kerja instan memperoleh presentasi paling besar dibanding lembar kerja yang dikembangkan oleh pendidik secara mandiri. lembar kerja yang bersumber dari buku paket dan internet termasuk kedalam lembar kerja instan dimana seorang pendidik hanya perlu menyiapkan lembar kerja dari buku paket atau internet untuk digunakan dalam pembelajaran sesuai dengan materi yang sedang dibahas. Fakta di lapangan masih banyak dijumpai pendidik yang masih menggunakan bahan ajar konvensional, yaitu bahan ajar yang tinggal pakai, tinggal beli, instan serta tanpa upaya merencanakan, menyiapkan dan menyusunnya secara mandiri. resikonya sangat dimungkinkan jika bahan ajar yang dipakai itu tidak kontekstual, tidak menarik, monoton dan tidak sesuai dengan kebutuhan peserta didik

Lembar kerja peserta didik saat ini telah mengalami banyak pengembangan sehingga terdapat berbagai jenis lembar kerja sesuai dengan perangkat yang digunakan. Jenis lembar kerja yang menjadi acuan penelitian ini antara lain lembar kerja cetak, lembar kerja elektronik, dan lembar kerja mobile. Lembar kerja cetak merupakan lembar kerja dalam bentuk cetak baik itu dalam bentuk buku maupun lembaran. Lembar kerja elektronik adalah lembar kerja yang menggunakan perangkat 
komputer atau laptop. Sedangkan lembar kerja mobile merupakan lembar kerja yang menggunakan perangkat smartphone atau tablet. Berdasarkan data yang diperoleh pada TABEL 2 menunjukkan bahwa $65 \%$ peserta didik menggunakan lembar kerja cetak, $10 \%$ menggunakan lembar kerja elektronik dan $25 \%$ menggunakan lembar kerja mobile. Hal tersebut menjelaskan bahwa lembar kerja cetak adalah lembar kerja yang paling banyak digunakan oleh peserta didik saat ini dilapangan. Masih sedikit pendidik yang memanfaatkan teknologi pada lembar kerja untuk digunakan dalam proses pembelajaran. Kepraktisan dalam hal penggunaan dan biaya yang dikeluarkan tergolong murah merupakan kelebihan yang dimiliki oleh bahan ajar cetak dibandingkan bahan ajar elektronik. Akan tetapi dari segi keefektifan dalam proses pemahaman peserta didik, bahan ajar elektronik tentunya lebih uggul. jika ditinjau dari manfaatnya media elektronik sendiri dapat menjadikan proses pembelajaran lebih menarik, interaktif, dapat dilakukan kapan dan dimana saja serta dapat meningkatkan kualitas pembelajaran Dari kedua jenis lembar kerja tersebut, lembar kerja mobile merupakan solusi dari kekurangan yang dimiliki oleh lembar kerja cetak dan elektronik dimana lembar kerja mobile juga praktis digunakan dan efektif karena memiliki fungsi yang hampir serupa dengan lembar kerja elektronik.

Peran media sangat diperlukan dalam lembar kerja peserta didik. Media berfungsi untuk mempermudah pemahaman peserta didik dalam proses pembelajaran. Berdasarkan data yang diperoleh pada TABEL 3 menunjukkan bahwa media gambar memiliki presentasi sebesar 59,2\%, media video sebesar $15,6 \%$, media animasi sebesar $4,4 \%$ dan media simulasi $20,8 \%$. Hal tersebut menunjukkan bahwa sebagian besar media yang terdapat dalam lembar kerja yang digunakan peserta didik adalah media gambar sebagaimana sesuai dengan jenis lembar kerja yang masih banyak digunakan adalah lembar kerja cetak. Media gambar tergolong kedalam media visual yang hanya memiliki unsur gambar. Selain itu, ada media audio visual yang memiliki unsur suara dan unsur gambar seperti video, animasi dan lainnya. Jenis media audio visual ini memiliki kemampuan lebih baik karena meliputi suara dan gambar Selain itu media audio visual mengabungkan dari beberapa indra manusia, peserta didik tidak hanya mendengarkan apa yang dijelaskan pendidik saja tetapi juga melihat kenyataan-kenyataan apa yang ditampilkan oleh pendidik dalam media tersebut Oleh karena itu perlu adanya pengembangan pada lembar kerja cetak menjadi elektronik atau digital yang dapat didukung oleh media video agar proses pemahaman peserta didik dalam proses pembelajaran menjadi lebih baik.

Adapun tanggapan lainnya dari peserta didik terhadap pengembangan lembar kerja peserta didik berbasis android antara lain: desain tampilan lembar kerja yang dikembangkan harus semenarik mungkin; peserta didik diharapkan dapat menulis langsung jawaban pada lembar kerja secara online tanpa menggunakan kertas; lembar kerja berbasis android yang dikembangkan diharapkan memiliki kelebihan dari segi kepraktisan dan keefektifan yang baik; lembar kerja peserta didik berbasis android diharapkan memiliki fitur penyimpanan secara online sehingga hasil kerja peserta didik dapat tersimpan secara lebih aman; kemudian, peserta didik mengharapkan adanya video sebagai media dalam lembar kerja sehingga dapat lebih mempermudah pemahaman peserta didik. Pengembangan lembar kerja berbasis android yang akan dilaksanakan diharapkan dapat memberikan pemahaman dan kemudahan bagi pendidik maupun peserta didik dalam mencapai tujuan pembelajaran yang telah dirancang.

\section{SIMPULAN}

Hasil studi pendahuluan pengembangan lembar kerja peserta didik berbasis android menunjukkan bahwa perlu adanya pengembangan lembar kerja peserta didik berbasis android yang dapat mendukung proses pembelajaran menjadi lebih efektif. Penggunaan media gambar dan video, serta desain tampilan yang menarik dapat meningkatkan pemahaman dan menarik minat peserta didik. Selain itu, penyimpanan data secara online juga diperlukan oleh peserta didik agar data hasil kerja peserta didik dapat tersimpan secara aman dan lebih praktis. Adapun tambahan fitur lainnya diharapkan dapat mempermudah peserta didik dalam proses pembelajaran dikelas.

Berdasarkan dari hasil studi pendahuluan pengembangan lembar kerja peserta didik berbasis android ini penulis menyarankan, hendaknya peneliti selanjutnya yang ingin melakukan studi 
pendahuluan lebih lanjut dapat memahami keterbatasan yang ada sehingga dapat melalukan studi pendahuluan yang lebih baik dan lebih akurat

\section{UCAPAN TERIMAKASIH}

Terimakasih kepada seluruh pihak yang telah membantu dalam penyelasaian jurnal ini, terimakasih juga kepada Bapak Dr. Acep Kusdiwelirawan, M.MSI. selaku dosen yang teleh membimbing dan membantu dalam pembuatan jurnal ilmiah, semoga dapat bermanfaat bagi penulis maupun pembaca.

\section{REFERENSI}

[1] S. Lestari, "Peran Teknologi dalam Pendidikan di Era Globalisasi," in Edureligia: Jurnal Pendidikan Agama Islam, vol. 2, no. 2, pp. 94-100, 2018.

[2] L. Rokhmah, F. Gulö and R. Edi, "Pengembangan Lembar Kerja Peserta Didik (LKPD) Interaktif Berbasis Komputer Untuk Pembelajaran Sistem Periodik Unsur Kelas X SMA," in Seminar Nasional Pendidikan IPA, vol. 1, no. 1, pp. 338-347, 2017.

[3] I. S. Utami, M. Vitasari, I. Langitasari, I. Sugihartono, and Y. Rahmawati, "The Local Wisdom-Based STEM Worksheet to Enhance the Conceptual Understanding of Pre-service Physics Teacher", JPPPF (Jurnal Penelitian dan Pengembangan Pendidikan Fisika), vol. 6, no. 1, pp. 97 - 104, Jun. 2020.

[4] L. C. Elwi, F. Festiyed, and D. Djusmaini, "Pembuatan Lembar Kerja Peserta Didik (lkpd) Multimedia Interaktif Menggunakan Course Lab Berbasis Pendekatan Saintifik Pada Pembelajaran Fisika Kelas X SMA/MA," in Journal Pillar of Physics Education, vol. 9, no. 1, pp. 97-104, 2017.

[5] Y. Yudhanto dan A. Wijayanto, "Mudah Membuat dan Berbisnis Aplikasi dengan Android Studio," Jakarta, Indonesia:PT Elex Media Komputindo, p. 1, 2017.

[6] D. Ambarwulan and D. Muliyati, "The Design of Augmented Reality Application as Learning Media Marker-Based for Android Smartphone", JPPPF (Jurnal Penelitian dan Pengembangan Pendidikan Fisika), vol. 2, no. 1, pp. 73 - 80, Jun. 2016.

[7] L. Aidin, N. Indahwati and A. Priambodo, "Pengembangan Aplikasi Lembar Kerja Peserta Didik (LKPD) PJOK Berbasis Android Pada Sekolah Menengah Kejuruan," in e-Jurnal Mitra Pendidikan, vol. 3, no. 2, pp. 226-240, 2019.

[8] R. Nurmalasari et al., "Peran Guru dalam implementasi Kurikulum 2013," in Jurnal Berkala Program Pascasarjana UM Malang, pp.722-733, 2016.

[9] M. Purbiyanto and H. Abdullah, "Peningkatan Kemampuan Menulis Karangan Tema 8 "Daerah Tempat Tinggalku" Dengan Menggunakan Media Gambar Berseri Berbasis Android," Jurnal Penelitian Pendidikan Guru Sekolah Dasar, 2019. 